\title{
Development of floating-leaved vegetation in three lakes of varied trophy (Leczna-Wlodawa Lakeland)
}

\author{
Joanna Sender \\ Department of Landscape Ecology and Nature Protection, University of Life Science in Lublin, 20-262 Lublin, Dobrzańskiego 37, Po- \\ land; e-mail: joanna.sender@up.lublin.pl
}

\begin{abstract}
Nymphaeids are a typical component of littoral vegetation in European lakes. In different types of water bodies they create large stands. This group of macrophyte species grows not deeper than 3 metres, but depending on clarity and depth. The aim of this study was to determine the percentage share and biomass of nymphaeids in investigated lakes with varying trophy and way of use. Furthermore, another aim of the study was a comparative analysis of morphometric features among dominant species of nymphaeids. The studied lakes are a group of eutrophic lakes, in various stages of its advancement from the low eutrophic Lake Płotycze Sobiborskie, through the eutrophic Lake Płotycze Urszulińskie to the highly eutrophic Lake Zienkowskie. In the studied lakes, nymphaeids formed a large part of the phytolittoral as well as macrophyte biomass, the smallest in the strongly eutrophic lake, the largest in the eutrophic lake. In the studied lakes appeared both Nymphaea candida species as well as intermediate forms. Neither the use of the lake nor habitat conditions affected the differentiation of the analysed characteristics of Nuphar lutea, while the most sensitive species was Nymphaea candida.
\end{abstract}

Key words: nymphaeids, Nymphaea candida, macrophytes, morphometric features

\section{Introduction}

Nymphaeids are aquatic plants which possess mainly floating leaves, have their flowers above or floating on the water surface and are rooted in the bottom. They represent different families of vascular plants such as Menyanthaceae, Nymphaeaceae, Potamogetonaceae, etc. They are a typical component of littoral vegetation in European lakes. In different types of water bodies they create large stands mainly dominated by one species (Szańkowski and Kłosowski 1999). Among seven nymphaeid communities found in Poland, the most common in our waters are Nymphaeetum candidae Miljan 1958, Potametum natantis Soó 1923, Polygonetum natantis Soó 1923, NupharoNymphaeetum albae Tomasz. 1977. Some of them are typical of clean, less fertile water, while others have a wide range of tolerance to habitat conditions (Kłosowski 2001). Structurally nymphaeids can be considered as intermediate between helophytes and submerged aquatic plants. In general, this group of macrophyte species grows not deeper than 3 metres, but depending on clarity and depth of water they can settle some metres deeper, but then are usually not able to form floating leaves (van der Velde 1980).

The aim of this study was to determine the percentage share and biomass of nymphaeids in investigated lakes with varying trophy and way of use. Furthermore, another aim of the study was a comparative analysis of morphometric features among dominant species of nymphaeids.

\section{Material and methods}

The study was conducted in the years 2009-2010 on three lakes, situated in the Łęczyńsko-Włodawskie Lakeland. The different habitat conditions of those lakes permitted a comparison of changes in species composition of flora, resulting from the different eutrophy level of waters.

The investigated lakes were diverse in terms of water surface, depth, usage, and eutrophy level (Table 
Table 1. Basic morphometric data and depth of macrophyte occurrence for lakes under study acc. Michalczyk and Wilgat 1998 , $\left({ }^{\star}\right.$ own research)

\begin{tabular}{|c|c|c|c|c|}
\hline \multicolumn{2}{|l|}{ Feature } & \multirow{2}{*}{$\begin{array}{l}\text { Lake Płotycze Sobiborskie } \\
\qquad 650\end{array}$} & \multirow{2}{*}{$\begin{array}{c}\text { Lake Płotycze } \\
\text { Urszulińskie }\end{array}$} & \multirow{2}{*}{$\begin{array}{c}\text { Lake Zienkowskie } \\
373\end{array}$} \\
\hline length & {$[\mathrm{m}]$} & & & \\
\hline surface area & [ha] & 15.8 & 10.6 & 7.6 \\
\hline \multirow[t]{3}{*}{ width } & {$[\mathrm{m}]$} & & & \\
\hline & & 400 & 365 & 285 \\
\hline & & 255 & 272 & 204 \\
\hline shape index & [nd] & 0.39 & 0.70 & 0.55 \\
\hline shore line & {$[\mathrm{m}]$} & 1775 & 1185 & 1113 \\
\hline \multirow[t]{3}{*}{ depth } & {$[\mathrm{m}]$} & & & \\
\hline & & 8.1 & n.det. & 4.9 \\
\hline & & 2.2 & $1.7^{*}$ & 2.7 \\
\hline depth of macrophyte occurrence* & {$[\mathrm{m}]$} & 1.5 & 1.7 & 1.2 \\
\hline usage & & $\begin{array}{c}\text { Nature Reserve, Natura 2000, } \\
\text { Landscape Park }\end{array}$ & Natura 2000 & Landscape Park \\
\hline
\end{tabular}

1). The lakes were covered by various forms of nature conservation. Lake Zienkowskie, through which flows the Piwonia Północna river, serves also as an intermediate receiver of urban waste water from nearby settlements. The main uses of the catchment area are as meadows and pastures. Lake Płotycze Sobiborskie is the largest among the studied lakes. Surrounded mostly by forest catchment, it is situated in a nature reserve "Three Lakes". Dominant ways of use of the catchment area of Lake Płotycze Urszulińskie are meadows, pastures, forests and land used intensively for agriculture.

The phytolittoral surface and participation of various plant communities, with particular emphasis on nymphaeids were described. Specified the phytolittoral surface and participation of various plant communities, with particular emphasis on nymphaeids. In phytosociological investigations, Braun Blanquet's method (1951) was used. Phytosociological units were distinguished on the basis of a systematic system and follow Matuszkiewicz's nomenclature (2008). The phytolittoral surface was determined according to field investigations and aerial photos using the Macrostation vr. 8 programme.

In order to verify the presence of Nymphaea candida Nowak's method was used based on 10 characteristics, verified in fresh material (Nowak and Nowak 2007). Moreover the investigations included qualitative analysis of macrophytes (determination of the area covered by plants), quantitative analysis (determination of total biomass of macrophytes and in- dividual vegetation groups, assessment of plant diversity).Emergent macrophytes were analysed using the floristic rake, while the submerged macrophytes using the floristic anchor (Bernatowicz 1960). The total macrophyte biomass (TMB) in the lake was estimated by the following equation (Canfield et al. 1983):

$\mathrm{TMB}=S A \times C \times B$

where: $S A=$ lake surface area, $C=$ percentage cover of submersed and floating-leaved aquatic macrophytes, and $B=$ average biomass collected with a sampler.

Variation in morphometric traits, density and biomass among the dominant species of nymphaeids in the studied lakes was also determined. Samples of nymphaeids were taken at a water depth of 50-100 cm at a distance of $3 \mathrm{~m}$ from banks by means of a $80 \times 80$ $\mathrm{cm}$ frame made of PVC tubes. A surface of $0.64 \mathrm{~m}^{2}$ per sample was dug out. Twelve samples were taken in the vegetative period in 2009, as well as in 2010. The length and in the case of leaf blades also the width were measured and the number of leaves was counted. The plant material was cleaned as well as possible by washing with tap water. The density of nymphaeids was determined by the formula $\pi r^{2}$, where $r$ - radius, and the surface of each leaf blade was calculated by the formula (van der Velde et al. 1979):

$\pi(l+w / 4)^{2}$

$l$ - is the leaf length measured from the leaf tip to the tip of the basal lobe

$w$ - is the maximum width of the leaf. 
Physical and chemical factors of the water were analysed such as $\mathrm{pH}$, temperature, electrolytic conductivity, oxygen content, total $\mathrm{P}$, total $\mathrm{N}$. The following instruments were used for the determination of physical and chemical properties of water: OXI 330 oxymeter (oxygen content, temperature), electronic conductivity meter (electrolytic conductivity), microchip Slandi SP300 pH-meter (water reaction). The content of biogenic nitrogen and phosphorus compounds was determined using the microchip Slandi photometer LF 205. For all lakes Carlson's (1977) Trophic State Index (TSI) was calculated, based on the visibility of a Secchi disk (SD), nitrogen (TN) and phosphorus (TP) content.

\section{Results and discussion}

The studied lakes represent eutrophic lakes at different stages of their advancement. This is confirmed by the Carlson index, Lake Zienkowskie - highly eutrophic; Lakes Płotycze Urszulińskie - eutrophic; and Sobiborskie - moderately eutrophic (Table 2).

According to some authors Lake Płotycze Sobiborskie is classified as a type of mesohumic lake (Chmiel 2008). In the investigated lakes $\mathrm{N}: \mathrm{P}$ ratio was higher than 16, which points to relative phosphorus deficiency (Table 2). Such a situation, from one side, is conducive to low trophic status, but on the other it could indicate instability of the ecosystem (HillbrichtIlkowska and Wiśniewski 1994).
The area occupied by plants in all studied lakes was different and averaged $47 \%$ of their surface, which puts them above the average for other Polish lakes (Kłosowski 1999). The largest phytolittoral occurred in Lake Płotycze Urszulińskie and the smallest in Lake Zienkowskie. The number of plant communities creating the phytolittoral was also varied. The most communities developed in Lake Płotycze Sobiborskie - 12 -while in Lake Zienkowskie only 6 (Table 3).

Nymphaeids played a significant part in creating the phytolittoral in the studied lakes. The largest area occupied by plants with floating leaves was in Lake Płotycze Urszulińskie, the smallest in Lake Zienkowskie. Almost half of the phytolittoral - 48\% - was formed by nymphaeids in Lake Płotycze Sobiborskie. In other lakes, Zienkowskie and Płotycze Urszulińskie, nymphaeids occupied respectively $37 \%$ and $30 \%$.

Rushes were the most numerous in all studied lakes. The least numerous were submerged plant communities. There were no submerged plant communities in Lake Zienkowskie (Table 3).Among seven nymphaeid associations distinguished in Poland, 3 occurred in the investigated lakes of the Łęczyńsko-Włodawskie Lakeland: Potametum natantis Soo 1927, NupharoNymphaeetum albae Tomasz.1977, Nymphaeetum candidae Miljan, 1958. Most of them had already appeared in the 1950s in the studied lakes (Fijałkowski 1959). These communities have developed on the edge of the rushes in Lakes Płotycze Urszulińskie and So-

Table 2. Physical and chemical characteristics of water in investigated lakes and trophic state indices (mean values)

\begin{tabular}{|c|c|c|c|}
\hline Feature & Lake Płotycze Urszulińskie & Lake Zienkowskie & Lake Płotycze Sobiborskie \\
\hline Temperature $\left[{ }^{\circ} \mathrm{C}\right]$ & 26.3 & 26.1 & 23.8 \\
\hline Visibility [m] & 1.2 & 0.2 & 1.05 \\
\hline Water reaction $[\mathrm{pH}]$ & 7.3 & 7.6 & 7.2 \\
\hline Conductivity $\left[\mu \mathrm{S} \mathrm{cm}^{-1}\right]$ & 196.6 & 260.4 & 44.9 \\
\hline Dissolved oxygen [mg dm-3] & 2.9 & 1.5 & 8.2 \\
\hline Oxygen saturation [\%] & 33.7 & 20.2 & 108.1 \\
\hline Total nitrogen $\left[\mathrm{mg} \mathrm{dm}^{-3}\right]$ & 1.99 & 2.95 & 1.49 \\
\hline Total phosporus [mg dm ${ }^{-3}$ ] & 0.069 & 0.179 & 0.055 \\
\hline Hardness [mg dm $\left.{ }^{-3}\right]$ & 3.56 & 6.39 & 1.27 \\
\hline TSI(SD) & 58.6 & 83.2 & 59.3 \\
\hline TSI(TP) & 65 & 79 & 62 \\
\hline TSI(TN) & 47 & 75 & 27 \\
\hline Carlson's TSI & 57 & 79 & 50 \\
\hline $\mathrm{N}: \mathrm{P}$ & 29 & 16 & 27 \\
\hline Trophy & eutrophy & highly eutrophic & moderately eutrophic \\
\hline
\end{tabular}


Table 3. Phytolittoral surface and particular plant associations in investigated lakes

\begin{tabular}{|c|c|c|c|c|c|c|c|}
\hline \multirow{2}{*}{$\begin{array}{l}\text { Group } \\
\text { of water } \\
\text { plants }\end{array}$} & \multirow{2}{*}{ Plant associations } & \multicolumn{2}{|c|}{$\begin{array}{l}\text { Lake Płotycze } \\
\text { Sobiborskie }\end{array}$} & \multicolumn{2}{|c|}{$\begin{array}{l}\text { Lake Płotycze } \\
\text { Urszulińskie }\end{array}$} & \multicolumn{2}{|c|}{ Lake Zienkowskie } \\
\hline & & [ha] & [\%] & [ha] & {$[\%]$} & [ha] & [\%] \\
\hline \multirow{11}{*}{ emergent } & Phragmitetum australis & 1.9 & 11.4 & 1,6 & 15.1 & 0.68 & 8.9 \\
\hline & Typhetum latifoliae & 1.1 & 6.6 & 1.6 & 15.1 & 0.16 & 2.1 \\
\hline & Elocharitetum palustris & 0.1 & 0.6 & & & & \\
\hline & Scirpetum lacustris & 0.3 & 1.8 & & & & \\
\hline & Caricetum elatae & 0.3 & 1.8 & 0.2 & 1.9 & & \\
\hline & Caricetum paniculatae & 0.2 & 1.2 & & & & \\
\hline & Thelypteridi - Phragmitetum & & & 0.3 & 2.8 & & \\
\hline & Equisetum fluviatile & & & 0.4 & 4.8 & & \\
\hline & Caricetum vesicariae & 0.1 & 0.6 & & & & \\
\hline & Salicetum pentandro-cinereae & & & & & 0.2 & 2.6 \\
\hline & total & 4 & 12.6 & 4.1 & 39.7 & 1.04 & 13.6 \\
\hline \multirow{3}{*}{ submerged } & Scorpidio - Utricularietum minoris & 0.1 & 0.6 & & & & \\
\hline & Nitellopsidetum obtusa & & & 1.6 & 15.1 & & \\
\hline & total & 0.1 & 0.6 & 1.6 & 15.1 & 0 & 0 \\
\hline \multirow{3}{*}{ Pleuston } & Hydrocharitetum morsus-ranae & & & & & 0.13 & 1.7 \\
\hline & Lemno minoris - Salvinietum natantis & 0.4 & 2.4 & 0.2 & 1.9 & & \\
\hline & total & 0.4 & 2.4 & 0.2 & 1.9 & 0.13 & 1.7 \\
\hline \multirow{4}{*}{$\begin{array}{l}\text { Plant with } \\
\text { floating } \\
\text { leaves }\end{array}$} & Potametum natantis & 1.2 & 7.2 & & & 0.02 & 0.3 \\
\hline & Nupharo - Nymphaeetum albae & 1 & 6 & 2.3 & 21.7 & 0.47 & 6.2 \\
\hline & Nymphaeetum candidae & 0.2 & 1.2 & 1.2 & 11.3 & & \\
\hline & total & 2.4 & 14.4 & 3.5 & 33 & 0.49 & 6.5 \\
\hline \multicolumn{2}{|c|}{ Phytolittoral surface } & 6.9 & 30 & 9.4 & 89.7 & 1.66 & 21.8 \\
\hline
\end{tabular}

biborskie in contact with submerged vegetation, while in Lake Zienkowskie in open water.Nymphaea candida C. Presl is a Euro-Siberian species with the western range limit on the line of the Rhine; in Poland, it occurs only in the north-west (Wayda 2000). There are some data about its occurrence in different places in this region of Poland, among them in some parts of the Łęczyńsko-Włodawskie Lakeland (Nowak et al. 2010).

The preliminary study conducted on the occurrence and taxonomical differentiation of Nymphaea genus is the first step towards species recognition in the investigated lakes. Optimum development of communities with Nymphaea candida occurs in mesotrophic waters with an acidic medium, fairly rich in organic substances (Kłosowski 2001). Nymphaea candida and intermediate forms (Nymphaea alba $\times$ N.candida) based on the analysis of 10 features were found in the studied lakes. Intermediate forms occurred in Lakes Płotycze Urszulińskie and Zienkowskie.
The analysis of morphometric features based on three dominant species distinguished communities of Nymphaea alba. Nuphar lutea and Nymphaea candida. In Lake Zienkowskie Nymphaea candida did not create communities; there were only single specimens.

The density of nymphaeid leaves floating on the water surface was varied in the studied lakes, among the species tested. The largest concentration in all the lakes was exhibited by Nymphaea alba, while the smallest by Nymphaea candida (Table 4). A similar trend occurred in oxbow lakes of the River Waal in the Netherlands; however, their density was greater (van der Velde 1980).

Generally, participation of macrophytes in plant biomass production is different than their share of the phytolittoral surface. The largest producer of biomass in water ecosystems is rush vegetation, then nymphaeids (Kraska 1988; Sender 2010a,b). Nuphar lutea reached the highest values of biomass in the investigated lakes, while Nymphaea candida the lowest (Table 
Table 4. Mean density and biomass of some nymphaeids in investigated lakes

\begin{tabular}{|c|c|c|c|c|c|c|c|c|c|}
\hline \multirow[b]{2}{*}{ Lake } & \multicolumn{3}{|c|}{ Nymphaea alba } & \multicolumn{3}{|c|}{ Nymphaea candida } & \multicolumn{3}{|c|}{ Nuphar lutea } \\
\hline & $\begin{array}{l}\text { density } \\
\text { (ind } \mathrm{m}^{-2} \text { ) }\end{array}$ & $\begin{array}{l}\text { biomass } \\
\left(g_{\mathrm{sm}} \mathrm{m}^{-2}\right)\end{array}$ & $\begin{array}{l}B: D \\
\text { ratio }\end{array}$ & $\begin{array}{l}\text { density } \\
\text { (ind } \mathrm{m}^{-2} \text { ) }\end{array}$ & $\begin{array}{l}\text { biomass } \\
\left(g_{\mathrm{sm}} \mathrm{m}^{-2}\right)\end{array}$ & $\begin{array}{l}B: D \\
\text { ratio }\end{array}$ & $\begin{array}{l}\text { density } \\
\text { (ind } \mathrm{m}^{-2} \text { ) }\end{array}$ & $\begin{array}{l}\text { biomass } \\
\left(g_{\mathrm{sm}} \mathrm{m}^{-2}\right)\end{array}$ & $\begin{array}{l}\mathrm{B}: \mathrm{D} \\
\text { ratio }\end{array}$ \\
\hline Płotycze Urszulińskie & $8.7 \pm 1.3$ & 208.6 & 24 & $6.4 \pm 1.6$ & 168.5 & 26 & $7.2 \pm 1.7$ & 355.0 & 49 \\
\hline Płotycze Sobiborskie & $7.1 \pm 1.1$ & 196.4 & 28 & $5.1 \pm 1.4$ & 61.4 & 12 & $6.5 \pm 1.6$ & 304.4 & 47 \\
\hline Zienkowskie & $7.9 \pm 1.5$ & 297.6 & 38 & $3.6 \pm 0.5$ & 174.2 & 49 & $5.5 \pm 1.3$ & 592.2 & 108 \\
\hline
\end{tabular}

Table 5. Mean biomass of particular parts of investigated species ( \pm stand. deviation)

\begin{tabular}{cccccccc}
\hline \multirow{2}{*}{ Lake } & \multicolumn{2}{c}{ Nymphaea alba } & \multicolumn{2}{c}{ Nymphaea candida } & \multicolumn{2}{c}{ Nuphar lutea } \\
\cline { 2 - 7 } & leaf & petiole & leaf & petiole & leaf & petiole \\
\hline Płotycze Urszulińskie & $136 \pm 12$ & $125 \pm 9.0$ & $111 \pm 21$ & $92 \pm 2.4$ & $235 \pm 15$ & $264 \pm 24$ \\
\hline Płotycze Sobiborskie & $123 \pm 17$ & $56 \pm 6.4$ & $35 \pm 3.4$ & $46 \pm 3.5$ & $198 \pm 14$ & $133 \pm 16$ \\
\hline Zienkowskie & $120 \pm 15$ & $88 \pm 5.7$ & $109 \pm 27$ & $109 \pm 18$ & $555 \pm 70.1$ & $378 \pm 42$ \\
\hline
\end{tabular}

4). In Lake Zienkowskie all analysed species reached the highest values of biomass, while in Lake Płotycze Sobiborskie the lowest (Table 5).

For values of biomass, especially Nymphaea alba and $N$. candida visibility had a significant influence ( $\mathrm{r}=0.98, \mathrm{p}<0.05)$; in the case of Nuphar lutea this correlation was less significant $(\mathrm{r}=0.11, \mathrm{p}<0.05)$. A high correlation between the density of nymphaeids and biomass values was found only in moderately and highly eutrophic lakes $(\mathrm{r}=0.9, \mathrm{p}<0.05)$; in Lake Płotycze Urszulińskie, where the phytolittoral occupied over $80 \%$ of the water surface, such a relationship was not significant $(\mathrm{r}=0.1, \mathrm{p}<0.05)$. The bulk of the biomass of nymphaeids is leaves along with stalks; other parts such as flowers or buds have no material effect on the plant mass (Kraska 1988). The largest mass of leaves and petioles occurred in Nuphar lutea, while the smallest in Nymphaea candida in all of the studied lakes (Table 5). On average, leaf biomass was two times greater than the biomass of petioles.

The greatest diversity among nymphaeid species occurred in Lake Płotycze Urszulińskie, while the smallest in Lake Płotycze Sobiborskie. The most numerous were pleustonic plants as well as plants with floating leaves (Table 6).Habitat conditions of nymphaeid associations were discussed by Szańkowski and Kłosowski (1999). Studies have also been conducted on the ecology of some nymphaeid species diverse in terms temperature conditions (Kraska 1988), as well as phenology, production and decomposition of floating leaves (van der Velde 1980; Malthus et al. 1990).

An analysis of selected morphometric features of 3 nymphaeid species in eutrophic lakes shows certain tendencies.In all the studied lakes Nymphaea alba developed the largest number of leaves but with a small area. The largest area is displayed by leaves of Nuphar lutea (Table 7). All parts of this plant reached the highest value, regardless of the type of use of the lake. The studied features of Nymphaea candida evolved differently depending on the lake. Smaller values of the analysed features in the lake were attained in Płotycze Sobiborskie; in the other lakes, these values were higher than for Nymphaea alba (Table 7). The longest petioles in most of the analysed species have evolved in Lake Zienkowskie. The reason for this could be the difference in water level due to its rate flow.

In the studied lakes, the shape indicator was important as well as the degree of development of both belts of rushes and plants with floating leaves. This is confirmed by the high correlation index value $r=$ $1.00, \mathrm{p}<0.05$. The ratio of the development of rushes to nymphaeids was three times higher, while in Lake Zienkowskie more than 4 times larger $r=0.91, p<0,05$.

\section{Conclusions}

The studied lakes are a group of eutrophic lakes, in various stages of advancement from the low eutrophic Lake Płotycze Sobiborskie, through the eutrophic Lake Płotycze Urszulińskie to the highly eutrophic Lake Zienkowskie. In the studied lakes, nymphaeids formed a large part of the phytolittoral as well as macrophyte biomass, the smallest in the strongly eutrophic lake, the largest in the eutrophic lake. Neither the use of the lake nor the habitat conditions affected the differentiation of the analysed characteristics of Nuphar lutea, while the most sensitive species was Nymphaea candida. 
Table 6. Species composition and contribution of macrophytes in selected stands of nymphaeids

\begin{tabular}{|c|c|c|c|}
\hline Group of macrophyte species & Lake Płotycze Sobiborskie & Lake Płotycze Urszulińskie & Lake Zienkowskie \\
\hline \multicolumn{4}{|l|}{ Helophyte/emergent } \\
\hline Equisetum limosum & & + & \\
\hline Schoenoplectus lacustris & + & + & \\
\hline Phragmites australis & & & + \\
\hline Typha latifolia & & & + \\
\hline \multicolumn{4}{|l|}{ Pleustonie and plants with floating leaves } \\
\hline Lemna minor & + & ++ & ++ \\
\hline Lemna trisulca & & + & + \\
\hline Potamogeton natans & + & + & ++ \\
\hline Hydrocharis morsus-ranae & + & + & + \\
\hline Nuphar lutea & + & ++ & ++ \\
\hline Nymphaea alba & + & + & ++ \\
\hline Nymphaea candida & ++ & + & + \\
\hline Polygonum amphibium & + & & \\
\hline Utricularia vulgaris & & + & \\
\hline Spirodella polyrrhiza & & + & +++ \\
\hline \multicolumn{4}{|l|}{ Elodeids/submerged } \\
\hline Stratiotes aloides & & ++ & + \\
\hline Ceratophyllum demersum & & ++ & + \\
\hline Elodea canadensis & & + & \\
\hline Myriophyllum spicatum, Scorpidium scorpioides & + & + & \\
\hline Batrachium circinatum & & + & \\
\hline total & 9 & 16 & 12 \\
\hline
\end{tabular}

(+) - to $25 \%,(++)-25-50 \%,(+++)-$ above $50 \%$

Table 7. Mean biometrical values of leaves and petioles of investigated nymphaeid species

\begin{tabular}{|c|c|c|c|c|c|c|c|c|}
\hline Lake & nymphaeid species & & $\begin{array}{l}\text { Petiole } \\
\text { diameter } \\
{[\mathrm{mm}]}\end{array}$ & $\begin{array}{l}\text { Leaf width } \\
\quad[\mathrm{cm}]\end{array}$ & $\begin{array}{l}\text { Leaf length } \\
{[\mathrm{cm}]}\end{array}$ & $\begin{array}{l}\text { Leaf mass } \\
{[\mathrm{g}]}\end{array}$ & $\begin{array}{c}\text { Mass of } 1 \mathrm{~m} \\
\text { of petiole } \\
{[\mathrm{g}]}\end{array}$ & $\begin{array}{c}\text { Petiole } \\
\text { length } \\
{[\mathrm{m}]}\end{array}$ \\
\hline \multirow{6}{*}{$\begin{array}{l}\text { Płotycze } \\
\text { Sobiborskie }\end{array}$} & \multirow{2}{*}{ Nymphaea alba } & $x$ & 5.0 & 20.5 & 13.3 & 19.0 & 8.7 & 1.80 \\
\hline & & SD & 0.0 & 0.3 & 0.6 & 0.7 & 0.4 & \\
\hline & \multirow{2}{*}{ Nymphaea candida } & $x$ & 3.3 & 13.2 & 8.4 & 7.0 & 5.2 & 1.87 \\
\hline & & SD & 0.6 & 1.8 & 1.2 & 1.7 & 0.9 & \\
\hline & \multirow{2}{*}{ Nuphar lutea } & $x$ & 7.2 & 21.7 & 20.0 & 28.0 & 18.8 & 1.67 \\
\hline & & $S D$ & 0.9 & 2.8 & 3.0 & 8.3 & 10.8 & \\
\hline \multirow{6}{*}{$\begin{array}{l}\text { Płotycze } \\
\text { Urszulińskie }\end{array}$} & \multirow{2}{*}{ Nymphaea alba } & $x$ & 5.2 & 17.8 & 12.2 & 15.7 & 8.3 & 1.64 \\
\hline & & SD & 0.6 & 1.5 & 1.1 & 2.4 & 1.6 & \\
\hline & \multirow{2}{*}{ Nymphaea candida } & $x$ & 5.7 & 19.0 & 13.0 & 17.3 & 9.0 & 1.66 \\
\hline & & SD & 0.2 & 2.7 & 1.7 & 6.4 & 2.0 & \\
\hline & \multirow{2}{*}{ Nuphar lutea } & $x$ & 9.2 & 22.6 & 20.4 & 32.5 & 16.5 & 1.45 \\
\hline & & $S D$ & 1.2 & 1.1 & 0.6 & 2.2 & 7.3 & \\
\hline \multirow{6}{*}{ Zienkowskie } & \multirow{2}{*}{ Nymphaea alba } & $x$ & 5.9 & 21.9 & 14.0 & 21.7 & 16.0 & 1.86 \\
\hline & & SD & 2.1 & 8.6 & 5.7 & 1.2 & 11.9 & \\
\hline & \multirow{2}{*}{ Nymphaea candida } & $\mathrm{x}$ & 6.2 & 25.7 & 17.4 & 30.3 & 18.3 & 1.68 \\
\hline & & SD & 0.3 & 6.4 & 8.5 & 1.5 & 1.5 & \\
\hline & \multirow{2}{*}{ Nuphar lutea } & $x$ & 7.3 & 26.3 & 25.8 & 70.0 & 37.7 & 1.73 \\
\hline & & $S D$ & 2.5 & 45.4 & 34.0 & 17.8 & 29.7 & \\
\hline
\end{tabular}




\section{References}

Bernatowicz S., 1960, Metody badania roślinności naczyniowej w jeziorach (Methods of investigations of vascular plants in lakes), Rocz. Nauk Rol. 77(B-1): 61-78 (in Polish, English summary).

Braun-Blanquet J., 1951, Pflanzsozologie. Grundzüge der Vegetationskunde, Springer, Wien-New York, p. 631.

Canfield, D.E. Jr., Langeland K.A., Maceina M.J., Haller W.T., Shireman J.V., Jones J.R., 1983, Trophic state classification of lakes with aquatic macrophytes, Can. J. Fish. Aquat. Sci. 40: 1713-1718.

Carlson R.E. 1977. A trophic state index for lakes, Limnol. Oceanogr. 22: 361-369.

Chmiel S., 2008, Hydrochemical evaluation of dystrophy of the water bodies in the Łęczna and Włodawa area in the years 2000-2008, Limnol. Rev. 9(4): 153-158.

Fijałkowski D., 1959, Szata roślinna jezior ŁęczyńskoWłodawskich i przylegających torfowisk (Plant associations of Lakes situated between Łęczna and Włodawa and of peat-bogs adjacent to these lakes), Ann. UMCS B 14(3): 131-190 (in Polish, English summary).

Hillbricht-Ilkowska A.,Wiśniewski R.J., 1994,Zróżnicowanie troficzne jezior Suwalskiego Parku Krajobrazowego i jego otuliny - Stan obecny, zmiennosc wieloletnia, miejsce w klasyfikacji troficznej jezior (Trophic diversity of lakes of the Suwałki Landscape Park (Northeastern Poland) and its buffer zone. Current state, longterm variability and place in the trophic classification of lakes), [in:] Hillbricht-Ilkowska A., Wiśniewski R.J. (eds) Jeziora Suwalskiego Parku Krajobrazowego. Związki z krajobrazem, stan eutrofizacji i kierunki ochrony (Lakes of the Suwałki Landscape Park. Links with landscape, eutrophication and protection measures), Zesz. Nauk. Kom. Nauk. PAN „Człowiek i Środowisko” 7: 181-200 (in Polish, English summary).

Kłosowski S., 1999, Od syntaksonomii do synekologii, czyli o badaniach siedliskowych roślinności litoralowej i ich znaczeniu (From syntaxonomy to synecology, that is about habitat studies of the littoral vegetation and their meaning), Mat. Ogólnopolskiej Konf. Nauk. „Współczesne Kierunki Ekologii Badań Hydrobiologicznych", Supraśl: 29-36 (in Polish).

Kłosowski S., 2001, Grzybienie północne Nymphaea candida C. Presl, grążel drobny Nuphar pumila (Timm) DC, przesiąkra okółkowa Hidrylla verticillata (L. fil.) Royle., [in:] Kaźmierczakowa R., Zarzycki K. (ed.) Polska Czerwona Księga Roślin (The Polish Red Data Book of Plants), IB PAN, Kraków: p. 664 (in Polish, English summary).

Kraska M., 1988, Reakcje ekosystemu jeziornego na wody podgrzane ze szczególnym uwzględnieniem hydromakrofitów (Reactions of the lake ecosystem to heated waters with particular reference to aquatic macrophytes), Wyd. Nauk. UAM, Poznań, p. 200 (in Polish).
Malthus T.J., Best E.P., Dekker A.G., 1990, An assessment of the importance of emergent and floating-leaved macrophytes to trophic status in the Loosdrecht lakes (The Netherlands), Hydrobiologia 191: 257-263.

Matuszkiewicz W., 2008, Klucz do oznaczania zbiorowisk roślinnych Polski (Guidebook for identification of vegetation communities of Poland), Wyd. Nauk. PWN, Warszawa: p. 536 (in Polish).

Michalczyk Z., Wilgat T., 1998, Stosunki wodne Lubelszczyzny (Water conditions in the Lublin Province), Wyd. UMCS, Lublin, p. 168 (in Polish).

Nowak A., Nobis M., Dajdok Z., Zalewska-Gałosz J., Nowak S., Nobis A., Czerniawska-Kusz I., Kozak M., Stebel A., Bula R., Sugier P., Szlachetka A., Bena W., Trojecka A., Piwowarczyk R., Adamiec A., Krawczyk R., 2010, Revision of Nymphaea candida range - new data on the distribution and habitat preferences of the species in southern Poland, Acta Soc. Bot. Polon. 79(4): 333-350.

Nowak A., Nowak S., 2007, The problem of occurrence of Nymphaea candida C. Presl in the Opole Silesia, Opole Sci. Soc. Nature Journal 40: 25-33.

Sender J., 2010a, Przekształcenia struktury hydrobotanicznej pod wpływem czynników naturalnych i antropogenicznych wybranych płytkich jezior na Pojezierzu Łęczyńsko-Włodawskim (Changes in hydrobotanical structure under natural and anthropogenic pressure in selected lakes of Łęczyńsko-Włodawskie Lakeland), [in:] Nędzarek A., Kubiak J., Tórz A. (eds.) Anthropogenic and natural transformations of lakes. Vol. 4, PTLim, Szczecin: 111-118 (in Polish, English summary).

Sender J., 2010b, Długoterminowe zmiany struktury roślinności wodnej w makrofitowych jeziorach na Pojezierzu Łęczyńsko-Włodawskim (Long-term changes of macrophytes structure in macrophyte-dominated lakes situated on meadow catchment areas in the ŁęczyńskoWłodawskie Lakeland), Ann. UMCS 65(2): 154-167.

Szańkowski M., Kłosowski S., 1999, Habitat conditions of nymphaeids associations in Poland, Hydrobiologia 415: 177-185.

Van der Velde G., 1980, Studies in nymphaeid-dominated system, Stichting Studentenpres, Nijmegen, p. 163.

Van der Velde G., Giesen Th. G., Van der Heijden L., 1979, Structure, biomass and seasonal changes in biomass of Nymphoides peltata (Gmel.) O. Kuntze (Menyanthaceae) a preliminary study, Aquat. Bot. 7: 279-300.

Wayda M., 2000, The distribution of Nymphaea candida C. Presl. (Nymphaeceae) in Poland, Acta Soc. Bot. Pol. 69(1): 75-78. 